Article

\title{
Implementation of the ISO 26000 Guidelines on Active Participation and Community Development
}

\author{
Oscar Daniel Licandro ${ }^{1} * \mathbb{D}^{\mathbb{D}}$, Adán Guillermo Ramírez García ${ }^{2}$, Lisandro José Alvarado-Peña ${ }^{3}{ }^{(0}$, \\ Luis Alfredo Vega Osuna ${ }^{4}$ and Patricia Correa ${ }^{1}$ \\ 1 Department of Administration and Finance, Universidad Católica del Uruguay; Montevideo 11600, \\ Uruguay; MACORREA@ucu.edu.uy \\ 2 Northern Regional Center, Universidad Autónoma de Chapingo, Obregón 56235, Mexico; \\ gramirezg@taurus.chapingo.mx \\ 3 Microeconomics Department, Universidad del Zulia (Venezuela), Maracaibo 4011, Venezuela; \\ lisandroinvestigacion@gmail.com \\ 4 Economic and Administrative Academic Deparment, Universidad Autónoma de Occidente, Culiacan 80020, \\ Mexico; luisalfredovega922@gmail.com \\ * Correspondence: olicandr@ucu.edu.uy
}

Received: 22 July 2019; Accepted: 11 September 2019; Published: 16 September 2019

\begin{abstract}
The ISO 26000 Guidance provides valuable conceptual and methodological guidelines for making corporate social action an effective tool through which organizations contribute to the solution of social problems within the communities they operate. These guidelines focus on their potential to contribute to the institutional strengthening of the social institutions of these communities, as well as to empower, generate autonomy, and develop skills in their final beneficiaries. Nevertheless, the academic literature has paid little attention to these guidelines. This document presents the results of pioneering research which was intended to provide information on the application of corporate social action. For measurement, a battery of 24 indicators was built and included in a structured questionnaire which was applied to a non-probabilistic sample of companies that carry out social actions. It was found that most of them apply the guidelines to a large extent and that this application correlates with the importance they assign to corporate social responsibility, with the degree to which they have incorporated it into their management, and with the construction of alliances with social organizations. Also, it was found that the application of these guidelines is independent of knowledge of the Guide and the approach to social responsibility that companies adopt.
\end{abstract}

Keywords: corporate social responsibility; community; social action; social alliances; ISO 26000

\section{Introduction}

After almost two decades of the 21st century, the states and organizations of the third sector still cannot independently find solutions to the great social and environmental problems that affect humanity. This is particularly true in the case of poverty, which continues to be "a chronic problem, despite the unprecedented amounts of time and treasure dedicated to its elimination since the end of the Second World War", as reported by Austin and Chu (2006, p. 3) more than 10 years ago. In this new context, the company emerges as an actor that has useful economic, material, and technological resources to contribute to the solution of these problems. In addition, from different areas it is proposed that companies need, in order to be sustainable, for these problems to be reduced or disappear. Porter and Kramer (2011) suggest that companies need to be involved in the solution of social problems of their ecosystems, and propose that their own sustainability depends on their capacity to generate shared value with the other actors that compose them. The ISO 26000 Guidance establishes 
that the application of social responsibility in organizations aims contribute to sustainable development (ISO 2011). The World Business Council for Sustainable Development warned, also more than a decade ago, that "a planet with more than four billion poor people is much more like a global society failed" (WBCSD 2006, p. 4).

There is a long tradition of involvement of the company in the solutions to the social problems of the countries and regions where its operation is located. Corporate philanthropy, which has its origins in 19th-century Anglo-Saxon America, was strengthened after the Second World War, driven by the approach of corporate citizenship (Garriga and Melé 2004; Ramos and Periáñez 2003; Carroll 2015) and the first proposals on corporate social responsibility (CSR). In addition, in the 1970s the first experiences of corporate social marketing (CSM) appeared, aimed at strengthening the image of brands through their association with social causes valued by consumers. In general, philanthropy and the CSM are forms of intervention aimed at mitigating a problem, helping a disadvantaged group, promoting a behavioral change in society (for example responsibility in driving vehicles), or financing the activities of cultural, educational, or sports institutions. These forms of corporate social action are, in general, of a welfare type since they help to mitigate specific situations, but do not contribute to the development of competences, empowerment, and autonomy of the communities. Therefore, they are not useful to address in a sustainable way the solution to social problems.

On the other hand, the current concept of CSR, particularly the one based on the orientations of the ISO 26000 Guide, proposes that companies take a leading role in creating conditions that favor the sustainable development of the communities where their operation takes place. This guide establishes, explicitly, that CSR towards the community cannot be of an assistential nature, but must be oriented towards generating conditions that favor its empowerment, autonomy, and sustainability. It is noted there that CSR differs from philanthropy. ISO Guide 26000 proposes a set of guidelines to direct the contribution of the company to the solution of social problems under this approach. Despite its importance from the conceptual and practical points of view (derived from being proposed by one of the most prestigious institutions in the design of useful tools for business management), the academy seems to pay little attention to its definitions and orientations, as can be seen from the fact that its approach is practically non-existent in articles on CSR that are published in scientific journals.

This document presents the results of research on CSR actions aimed at communities, with the objective of assessing whether these actions are aligned with the guidelines of ISO 26000. The sample was constituted by the companies that have a public discourse of adoption of CSR in Uruguay and that fit their social actions under this concept. These guidelines were divided according to the two major dimensions proposed in ISO 26000 for CSR towards the community: active participation in the community (APC) and community development (CD). A battery of 24 indicators was built, 11 of which refer to the first dimension, and the remaining 13 represent different aspects of the second. A structured questionnaire was designed (mainly composed of closed questions) and was applied to those responsible for managing social actions in a non-probabilistic sample of 47 companies. It was found that most of them apply, to a large extent, the guidelines found in the guide, and that this application correlates with the importance they assign to corporate social responsibility, the degree to which they have incorporated it into their management, and the construction of alliances with social organizations. Also, it was found that the application of the guidelines of the ISO 26000 Guide on APC and CD does not depend on: (1) the approach to CSR that companies adopt and (2) the knowledge that managers have about the contents of that guide.

\section{Literature Review}

The theoretical framework that supports the research was based on: (1) a description of the main approaches to the concept of CSR, including the definition of this concept proposed in the ISO 26000 Guide; (2) a brief description of the guidelines established in the ISO 26000 Guide on CSR with the community; and (3) an analysis of the role of alliances in CSR application in the community 


\subsection{Approaches on the Concept of CSR}

Since academics began to reflect on the social responsibility of companies in the 1950s, it has evolved from an originally simple idea which associated CSR with philanthropy, to a more elaborate formulation which includes the different theoretical contributions produced during almost seven decades (Carroll 1999, 2015; Garriga and Melé 2004; Dahlsrud 2008; James 2012). Although it was not a linear process (rather consisting in the evolution of different but complementary views of the same phenomenon), this conceptual diversity has been included in the definition of social responsibility of organizations proposed in the ISO 26000 guide, in which it is possible to identify the synthesis of several of those views and the theories that support them. In this guide, social responsibility (SR) is defined as:

[...] responsibility of an organization for the impacts of its decisions and activities (products, services, and processes) on on society, through transparence and ethical behavior that

- contributes to sustainable development, including the health and welfare of society;

- takes into account the expectations of stakeholders;

- is in compliance with applicable law and consistent with international norms of behavior; and

- is integrated throughout the organization and practised in its relationships

(ISO 2011, p. 18)

This definition, which has broad consensus among institutional actors interested in promoting CSR, includes at least four different ways of interpreting this concept, present in the literature. They define CSR as (1) a contribution of the company to the society in which it operates; (2) incorporation into the management of stakeholder's expectations and demands; (2) responsible management of the impacts of the operation of the company on its stakeholders, society in general, and the environment; and (3) ethical management (business ethics). Below is a brief description of each of these ways of interpreting the concept of CSR.

CSR as a contribution of the company to society is a reductionist approach that interprets it as a business behavior parallel to the business, through which the company allocates resources to contribute to the solution of social problems or the improvement of society, including the environment. Within this conceptual framework, works by many of the first authors who reflected on the social responsibility of companies can be found. Steiner (1971, p. 164) proposed that the company has "responsibilities to help society achieve its basic objectives", while Eilbert and Parket (1973) affirmed that CSR is a commitment of the company to the solution of various social and environmental problems, including pollution and racial discrimination. Some authors warned about the great diversity of interpretations and uses of the concept: "Faced with the large number of different uses, and not always consistent, we restrict our own use of the term social responsibility to refer only to a sense of vague social concern and highly generalized that seems to underlie a wide variety of ad hoc management policies and practices" (Preston and Post 1975, p. 9).

Later, with the emergence of the concept of corporate citizenship in the 1980s, this way of interpreting the concept of CSR received strong support, as analyzed by Garriga and Melé (2004). Under this approach, as a corporate citizen, the company has a moral obligation to return to society the resources it uses for its operation. In return, the adoption of this type of behavior contributes to strengthening the reputation of the company and obtaining the recognition of society. In this line of thought, Barnett (2007) argues that CSR is a discretionary allocation of business resources aimed at improving social welfare, with the ultimate goal of strengthening the relationship with its key stakeholders. At this point, CSR can be confused with philanthropic activities and social marketing campaigns (Varadarajan and Menon 1988; Ramos and Periáñez 2003), as occurs with authors such as Kotler and Lee (2005). Lichtenstein et al. (2004, p. 16), reduce CSR to the fact that "that the company has to get involved in causes of charity and with the non-profit organizations that represent it". Kok et al. (2001, p. 187) defined it as "the obligation of the company to use its resources to benefit 
society, through committed participation as a member of society". Ramos and Periáñez $(2003$, p. 66) argued, at the beginning of the last decade, that various institutions that promote CSR conceive it as a social strategy of corporate citizenship, relations with the community, investment in the community, and corporate reputation.

In general, the authors that integrate this current of thought do not differentiate the community (concrete stakeholder) from the society (abstract entity, which is not usually defined operationally), being for them the latter the recipient of the social action of the companies. It should be noted that this way of interpreting CSR has lost strength in the academic world.

CSR as incorporation to the management of stakeholder expectations and demands is an idea that derives from the Theory of the Stakeholders by Freeman (1983). Johnson (1971) stated that CSR involves balancing the interests of multiple actors, including employees, suppliers, and local communities. Jones (1980, pp. 59-60) associated CSR with the idea that "corporations have an obligation to constituent groups of society that are not shareholders and beyond what is prescribed by law and the union contract". On the other hand, Khoury et al. (1999) affirmed that CSR refers to the general relationship of the company with all its stakeholders. Carroll (1999) argued that there is a natural coincidence between the concepts of CSR and stakeholder, while suggesting that the latter contributes to overcoming the ambiguity of the social term, because he "puts names and faces" (Carroll 1999, p. 290) to the groups of society that are most important to the companies and to which they must respond.

These ideas have been incorporated into the definition of social responsibility proposed in ISO 26000, stating that CSR must take into "consideration the expectations of its stakeholders" (ISO 2011, p. 106). Under this approach, the groups and specific institutions that are part of the environment where each company operates, and that therefore, are part of its stakeholders, become visible. Consequently, it is under this approach that the abstract concept of society materializes into concrete groups and organizations, which are being called community or local communities. This idea is collected by ISO Guide 26000, where the social actions of companies are directed towards the community and not towards society.

CSR as responsible management of the impacts of the operation of the company on stakeholders, society, and the environment is the central idea of the definition of social responsibility proposed in ISO 26000. This approach is already present in the thinking of some authors in the 1960s, such as Davis and Blomstrom (1966), who associated CSR with the idea that companies should consider the way their activity affects their needs and interests of other actors. This idea was developed later by other authors (e.g., Frederick et al. 1992), for whom CSR is "a principle that establishes that companies should be responsible for the effects of any of their actions in their community and his or her environment". Carroll (2015) observed that the socially responsible management of impacts includes, on the one hand, protecting society from the negative impacts of the operation of the company and, on the other, contributing to improving the conditions of society through positive impacts deliberately sought. Under this approach, the community is seen from the perspective of the management of the operational impacts of the company, which derives from the idea that the CSR consists in the generation of positive impacts through the use of the different resources involved in operation (human capital, goods and services, relational capital and know-how) when implementing social actions. In this way, CSR towards the community moves away from philanthropy. It is in this sense that ISO Guide 26000 clearly states that CSR is distinct from philanthropy.

The CSR reduced as Business Ethics. Zenisek (1979) proposed a model of social responsibility based on the relationship between business ethics and society's expectations. The WBCSD (2000, p. 8), defined CSR as "the continuous commitment of companies to behave ethically and contribute to economic development". On its part, the English organization Business for Social Responsibility (WBCSD 2000) first defined it as making business decisions linked to ethical values and later, as "open and transparent business practices based on ethical values and respect for employees, communities and the environment, which will contribute to sustainable business success "(James 2012, p. 70). Epstein (1987) noted that social responsibility and ethics address closely related and even overlapping issues and concerns. 
Hopkins (1998) stated that CSR is related to treating stakeholders ethically. According to Carroll (2015), in the second decade of the 21st century, the concept of business ethics has become part of the CSR concept.

\subsection{The Guidelines of the ISO 26000 Guide on CSR towards the Community}

According to the ISO 26000 guide, the socially responsible company not only tries to minimize its negative impacts on the community and the environment but also assumes a proactive attitude towards the social problems of its community. In that sense, this guide states that "active participation in the community goes beyond identifying and involving stakeholders in relation to the impacts of an organization's operations; it also includes support and identification with the community “(ISO 2011, p. 105). It later added: "The Copenhagen Declaration recognizes the urgent need to address profound social changes, especially poverty, unemployment and social marginalization" (ISO 2011, p. 107). Hence, the involvement of companies in the problems of the communities in which they operate and their commitment to their solution through both their productive and commercial activities (for example, by generating employment, improving the infrastructure they share with their communities, etc.) and specific activities directed to this end, is referred to in the literature as social action (Abad 2002; Recio and Martín 2002).

The name the ISO 26000 designates that this fundamental subject of the CSR is, in itself, an excellent synthesis of its meaning: active participation and development of the community. Active participation refers to involvement; which expressly suggests that support for the community cannot be reduced to "giving" from the outside. To participate is to get involved, or as explicitly stated in ISO 26000: "companies contribute to their communities through their participation and support in civil institutions, and through active participation in networks of groups and individuals that constitute civil society" (ISO 2011, p. 110). Active participation refers to three dimensions: (1) "proactive assistance" (ISO 2011, p. 109) through "participation and support to civil institutions" (p. 109) and "local associations" (p. 110), (2) dialogue to "consult the communities" (p. 109); and (3) promoting the involvement of other actors, in particular, to "encourage citizens to act as volunteers". The guidelines on active participation are brought together in the first of seven matters in which ISO 26000 divides this fundamental issue.

In Section seven (Social Investment), this guide defines the development of the community as "the improvement of the quality of life of a population" (p. 105) and, therefore, the actions oriented to that end cannot be reduced to assistance-type support, since they generate a dependency on who provides it. In this sense, it is recommended "to contribute to the increase of capacities, resources and opportunities" (p. 117) and "to encourage the active participation of the community in the design and implementation of projects" (p. 117). According to this guide, the development of the community is an integral part of sustainable development and, therefore, its focus must be on contributing to the creation of the conditions that make it possible. Hence, ISO 26000 focuses on addressing problems such as job creation, the promotion of education, the acquisition of skills for labor insertion, and inclusion in the market economy. In particular, this guide points out that the development of the community also involves "the institutional strengthening of the community, its groups and collective forums" (ISO 2011, p. 106).

\subsection{CSR towards the Community and Social Alliances}

In ISO 26000, companies are summoned to "recognize the value of working in partnership with other organizations, supporting the exchange of experiences, resources and efforts" (ISO 2011, p. 106). The creation of alliances to carry out social actions is a way of applying the guidelines of ISO 26000 established in Sections one (active participation) and seven (social investment) since, on the one hand, collaborative work with other institutions is a clear manifestation of involvement and commitment and, on the other hand, it is a more effective tool to generate sustainable impacts in the communities, than the individual work of each company. Peloza and Falkenberg (2009) study the contribution of alliances 
among diverse sectors in the application of CSR strategies. The analysis of cases on CSR towards the community in Uruguay (DERES 2015, 2016, 2017) shows that the success of these experiences depends to a large extent on forms of collaborative work with other institutions (non-governmental organizations (NGOs), community organizations, state agencies, etc.), which have allowed them to join efforts and complement capacities.

Social alliances are, among diverse sectors, defined as voluntary cooperation agreements between actors from two or more sectors of society, which have a non-hierarchical and not yet institutionalized structure and which seek to achieve sustainability goals (Glasbergen et al. 2007). The creation of new responses to problems of the social agenda has generated the emergence of forms of alliances between different institutional actors in the state, civil society, or private sectors, creating networks of public-private-civic articulation (Prats 2001). In that sense Austin et al. (2009, p. 94) affirm that the "paths of companies and CSOs have not only crossed but now converge", since both need each other to achieve their objectives. Although the literature on social organizations has long insisted on the need to coordinate with the private sector (mainly to access new sources of financing), what is new is the emergence of the same idea formulated in the literature of management. According to Dahan et al. (2010, p. 327) multinational companies require the support of NGOs to adapt their business models to the cultural, economic, institutional, and geographical characteristics of developing countries, since they lack the intangible resources that are needed for that purpose.

Collaboration processes (Austin 2003), where the know-how of each actor is put together, are the central node that makes possible the transfer of knowledge, collective learning, and a better approach to social problems from an optimal point of view, and use of the comparative advantages of the alliance (in particular, complementarities), thus allowing the creation of value. This is why the actors need each other, as social alliances are a proven tool for effective and efficient management of cooperation among them (Austin et al. 2004). Alliances allow actors to amplify their roles, incorporating new assets extracted from the interaction itself. The approach between the actors can adopt different formats and levels of depth. For this, the generation of trust between them becomes a point of great importance (Austin et al. 2005, p. 170), as well as a commitment (Austin et al. 2004, p. 6), with the conviction that the action that is being undertaken is of utmost importance for each of them (Austin et al. 2004, p. 6).

Despite its importance, empirical research on alliances between social organizations and companies is underdeveloped. After an initial push led by James Austin, within the framework of which several qualitative research based on case studies (Ramos et al. 2004; Austin et al. 2005; Social Enterprise Knowledge Network 2006; Alonso Ubieta et al. 2009) were conducted in Latin America and some European countries, the scientific production on the subject stagnated. The only exception is perhaps the study of alliances in the specific field of two similar strategies, designed in the 2000s to reduce poverty and allow the poorest sectors to access basic goods and services: inclusive businesses (Márquez et al. 2010; Licandro 2013) and the development of markets at the base of the pyramid (Prahalad and Hart 2002). In addition, it is important to note that the research on social alliances continues to be fundamentally of a qualitative nature.

Prahalad and Hart (2002) proposed that the development of prosperous markets at the base of the pyramid (BOP) is leveraged into four elements (creating purchasing power in the BOP, shaping their aspirations, improving their access, and adapting local solutions), whose construction no company can tackle on its own. For that reason, companies must work in collaboration with non-governmental organizations (NGOs), local governments, financial institutions, other companies, and the communities themselves. Hart and Christensen (2002) argued that the development of markets at the base of the pyramid requires building long-term relationships with other local institutional actors. Through the study of 24 cases, London and Hart (2004) show that multinational companies that are successful in the BOP markets have specific capacities for social roots and networking with local non-business partners. In this sense, these authors affirm that non-profit organizations and other social institutions can play an important role in the creation of businesses that favor BOP (London and Hart 2004). Hammond et al. (2007, p. 31) found that a successful general strategy for the development of this 
type of business is the creation of "unconventional associations with governments, NGOs or other actors that contribute skills or abilities critics". On the other hand, London and Anupindi (2012) show that intersectoral collaboration produces a set of strategies that allow achieving sustainable and scalable results in business development with the BOP. More recently, based on case studies, Pfitzer et al. (2013, p. 4) argue that companies that seek to simultaneously develop economic and social value are based on five elements, one of which is co-creation with those who help identify social needs and execute strategies. Among them are governments, foundations, universities, and NGOs.

In the case of inclusive business, Fisher et al. (2010, p. 212) argue that the "ability to build networks of allies with public institutions, non-governmental organizations and private companies has been decisive for the condition and sustainability of these initiatives through the generation of value". On the other hand, Reficco and Vernis (2010), help to understand the role of social alliances in the development of inclusive businesses, through what they call the "metaphor of the ecosystem". This is "an economic community supported by a base of organizations that interact and that revolve around the production of goods and services" (Reficco and Vernis 2010, p. 129). In this paper, Reficco and Vernis (2010) propose a model that includes the different types of actors that participate in the ecosystems and describe the role of each one of them. In a document that describes the results of a comparative research on inclusive business experiences in Latin America, Africa, and Asia, PNUD (2008) highlights the role of collaborative work among various institutional actors for the successful implementation of strategies aimed at lifting environmental restrictions that limit the possibilities of the poor to create and manage inclusive ventures. In Licandro (2013), seven contextual factors are identified that generate positive conditions for the development of inclusive businesses with waste classifiers ${ }^{1}$, one of which is the existence of institutional actors with the capacity to build alliances to promote this type of project.

The cooperative relations between actors of the third sector and companies can adopt different formats and degrees of depth. These relationships can move in a wide arc, ranging from punctual cooperation and little strategic value (which implies a low commitment and little interaction between the parties), to true alliances, characterized by being designed in the long term and by having an important strategic value for partners, with a high commitment and level of interaction between them. Austin et al. (2004) Austin et al.ualify as philanthropic the cooperation processes of the first end of that arc and as strategic alliances those of the other. In addition, Austin et al. (2004) propose a model based on eight dimensions, through which it is possible to evaluate the depth of cooperation between a company and a social organization: (1) level of commitment (from high to low), (2) importance of the alliance for the mission of the company (from peripheral to central); (3) the magnitude of the resources it provides (from low to high); (4) the types of resources it brings (from money to central capacities); (5) the spectrum of activities that are carried out (from narrow to broad); (6) level of interaction with the social organization (rare to intense), (7) administrative complexity of managing the alliance (from simple to complex); and (8) strategic value of the partnership (from minor to substantial).

\section{Research Problem and Hypothesis}

The research problems addressed in this document are described below and the hypotheses related to each of them are explained. The first problem refers to whether the companies in the sample are applying the guidelines of the ISO 26000 Guide regarding active community participation (ACP) and community development (CD). Although no previous research on this topic was found, the public information available on the practices of many of the companies that make up the sample suggests that an important part of them are applying these guidelines. This information also suggests that the companies that are most directly involved in implementing their social actions are those that prioritize the forms of intervention that are oriented towards the institutional strengthening of the community

1 In Uruguay they are called "hurgadores", in Argentina they are called "cartoneros", and in Brazil they are called "catadores". 
or the empowerment and development of competencies in the beneficiaries of their social actions. Therefore, the following hypotheses are proposed:

Hypothesis 1. Most of the companies in the sample follow the guidelines of the ISO 26000 Guide on ACP and CD.

Hypothesis 2. There is a correlation between the degree of incorporation of the guidelines of the ISO Guide 26000 on ACP and the degree of incorporation to the guidelines of this guide on CD.

The second problem deals with the relationship between the incorporation of CSR in companies and the degree to which they apply the orientations of the ISO 26000 Guide on ACP and CD. Three aspects are considered here: (1) the way in which the concept of CSR is interpreted by those responsible for managing social actions; (2) the importance assigned to CSR in each company; and (3) the effective degree of incorporation of CSR into management. Previous research suggests that executives of companies in Uruguay handle different CSR concepts, and that the interpretation of the CSR proposed in the ISO Guide 26000 (as responsible management of the operation's impacts) is shared only by a small part of them (Licandro et al. 2019). Based on this situation, the following hypothesis is proposed:

Hypothesis 3. The degree to which companies apply the guidelines of the ISO 26000 Guide relative to the ACP and the CD is independent of how the concept of CSR is interpreted by those responsible for managing their social actions.

In addition, it seems reasonable to assume that the application of the guidelines of the ISO 26000 Guide on ACP and CD must be greater among the companies that give more importance to CSR and among those that are more advanced in the incorporation of CSR to their management. Therefore, the following hypotheses are proposed:

Hypothesis 4. The degree to which companies apply the guidelines of the ISO 26000 Guide relative to the ACP and the CD is correlated with the importance assigned to CSR.

Hypothesis 5. The degree to which companies apply the guidelines of the ISO 26000 Guide relative to the ACP and the CD is correlated with the degree of incorporation of CSR to its management.

The third problem refers to the relationship between the knowledge of the ISO 26000 Guide and its effective application in terms of ACP and CD. It is possible to suppose that a greater knowledge of the contents of this guide has to impact the management of the CSR towards the community aligned with its orientations. Similarly, it seems reasonable to assume that the perception of the application of these contents must correspond to what companies actually do. Based on this, the following hypotheses are proposed:

Hypothesis 6. The degree to which companies apply the guidelines of the ISO Guide 26000 related to the ACP and the CD is correlated with the knowledge that the contents of this guide are responsible for managing CSR activities towards the community.

Hypothesis 7. The degree to which companies apply the guidelines of the ISO 26000 Guide regarding the ACP and the CD is correlated with the perception that those responsible for managing CSR towards the community have about the depth with which their companies apply said orientations.

Finally, the fourth problem analyzes the relationship between the application of the guidelines of the ISO 26000 Guide on ACP and CD with the collaborative work of companies with public and social institutions. Given that active participation in the community includes this type of work, it seems reasonable to assume that companies that implement strategic alliances with actors, 
social organizations, and public institutions must apply these guidelines in greater depth than those that do not implement them.

Hypothesis 8. In the case of companies that maintain collaborative working relationships with public or private institutions, the extent to which they apply the guidelines of the ISO 26000 Guide relative to the ACP and the $\mathrm{CD}$ is correlated with the degree of depth of the alliances.

\section{Methodology}

The population was constituted by the companies that have a public discourse of adoption of CSR in Uruguay (that is, companies that disseminate their CSR practices on their websites, newspapers, or public events) and that fit their social actions under this concept. These are companies that carry out social actions systematically and that fit them into permanent programs. The broad spectrum of companies that carried out isolated social actions or those outside the framework of CSR was left out. To identify the companies, a secondary information review was carried out (press articles, websites of the companies that disseminate their social actions, and various databases previously generated by the CSR Research Program of the Catholic University of Uruguay), from which a database with 178 companies was built. The sample consisted of 47 companies from that database that agreed to participate in the investigation. Therefore, it is a non-probabilistic sample. A structured questionnaire was designed (mainly composed of closed questions) to be answered by the person in charge of managing the social actions in each company. It was foreseen that its application would be carried out through one of two possible survey techniques (self-administered or personal interview), to be chosen by each interviewee. The fieldwork was carried out during 2018 and the first months of 2019. The information was processed using the statistical software SPSS 23.

Eleven indicators were used to assess the application of the ISO 26000 guidance on ACP (see Table 1) and 13 to assess the application of the CD guidelines (see Table 2). The former were divided into four categories related to collaborative work with institutions (2); the use of corporate volunteering (2); the planning of activities (3); and practices in terms of monitoring and evaluation (4). On the other hand, the CD indicators were divided into two categories, according to whether the actions were aimed at the institutional strengthening of the community (5) or the empowerment and development of skills in the beneficiaries (8). All these indicators were measured with a nominal scale of two values (applied or not applied). Based on them, two numerical scales were constructed that measure the degree to which each company applies the orientations of the ISO 26000 Guide in terms of ACP and CD. These scales indicate the proportion of practices that each company applies in each of these dimensions (SCAACP and SCACD).

Table 1. Indicator of active community participation (ACP).

\begin{tabular}{|c|c|c|c|}
\hline Dimension & Code & Indicators & Applicable \\
\hline \multirow{2}{*}{$\begin{array}{l}\text { Collaborative work } \\
\text { with institutions }\end{array}$} & ACP1 & $\begin{array}{l}\text { Maintain permanent alliances with social organizations and/or } \\
\text { public institutions }\end{array}$ & $85 \%$ \\
\hline & ACP2 & $\begin{array}{c}\text { Have people assigned to the management of the relationship with } \\
\text { institutions }\end{array}$ & $77 \%$ \\
\hline \multirow{2}{*}{ CV usage } & ACP3 & Volunteering of employees & $77 \%$ \\
\hline & $\mathrm{ACP} 4$ & Volunteering of managers and/or CEOs & $64 \%$ \\
\hline \multirow{3}{*}{ Planning } & ACP5 & There is an annual plan of activities & $91 \%$ \\
\hline & ACP6 & There is an annual budget & $85 \%$ \\
\hline & ACP7 & It is incorporated in the general strategic planning of the company & $89 \%$ \\
\hline \multirow{4}{*}{$\begin{array}{l}\text { Monitoring and } \\
\text { evaluation }\end{array}$} & ACP8 & There are monitoring indicators & $81 \%$ \\
\hline & ACP9 & The operation of the activities is evaluated after the functioning & $85 \%$ \\
\hline & ACP10 & $\begin{array}{c}\text { The impact/benefits of the activities for the beneficiaries are } \\
\text { identified/evaluated or measured }\end{array}$ & $51 \%$ \\
\hline & $\mathrm{ACP} 11$ & $\begin{array}{c}\text { The impact/benefits of the activities for the company are } \\
\text { identified/evaluated or measured }\end{array}$ & $51 \%$ \\
\hline
\end{tabular}


Table 2. Indicators of community development (CD).

\begin{tabular}{|c|c|c|c|}
\hline Dimension & Code & Indicators & Applicable \\
\hline \multirow{5}{*}{$\begin{array}{l}\text { Actions aimed at the } \\
\text { institutional } \\
\text { strengthening of the } \\
\text { community }\end{array}$} & CD1 & $\begin{array}{l}\text { Advises the institutions with which it collaborates } \\
\text { in matters of management or management }\end{array}$ & $45 \%$ \\
\hline & $\mathrm{CD} 2$ & Transfers technical knowledge & $70 \%$ \\
\hline & CD3 & Provides access to technology & $51 \%$ \\
\hline & CD4 & Provides support for fundraising & $26 \%$ \\
\hline & CD5 & $\begin{array}{c}\text { CEOs and managers are integrated into the boards } \\
\text { of social organizations }\end{array}$ & $26 \%$ \\
\hline \multirow{8}{*}{$\begin{array}{l}\text { Actions directed to the } \\
\text { empowerment and the } \\
\text { development of } \\
\text { competences in the } \\
\text { beneficiaries }\end{array}$} & CD6 & Supports education (formal or informal) & $91 \%$ \\
\hline & CD7 & Supports labor insertion (training, hiring, etc.) & $72 \%$ \\
\hline & CD8 & Promotes the development of entrepreneurial skills & $47 \%$ \\
\hline & CD9 & $\begin{array}{c}\text { Supports the labor inclusion of people with } \\
\text { difficulties to get work }\end{array}$ & $47 \%$ \\
\hline & CD10 & Provides tutorials & $28 \%$ \\
\hline & CD11 & Provides internships & $64 \%$ \\
\hline & CD12 & $\begin{array}{c}\text { Training activities performed by company } \\
\text { personnel }\end{array}$ & $70 \%$ \\
\hline & CD13 & Supports inclusive ventures & $34 \%$ \\
\hline
\end{tabular}

\section{Analysis of the Results}

Table 1 shows that eight of the 11 ACP practices are used by more than $75 \%$ of the companies in the sample. This situation is registered in all the indicators on collaborative work with institutions (both public and civil society) and on the use of planning tools for social actions. Volunteering of employees is also found in this situation (77\%), but the percentage of companies that use volunteer work by managers $(64 \%)$ was somewhat lower. Regarding monitoring and evaluation practices, it is recorded that the former is carried out in a greater proportion than the latter. Nevertheless, the evaluation of the impacts of the activities for the beneficiaries and for the companies is used by half of the companies. It should also be noted that $21 \%$ of companies apply 10 of these practices, $38 \%$ apply eight or nine of them, and $30 \%$ do so with six or seven practices. As a whole, these data suggest that among the companies in the sample, those that apply the guidelines of the ISO Guide 26000 relating to active community participation predominate.

Table 2 shows the percentage of companies that perform each of the 13 practices related to the recommendations of the ISO 26000 Guidance about community development. There it is possible to observe that, in general, the percentages are lower than those registered in the ACP indicators. This is explained by the fact that, while these refer to general and cross-cutting practices that any company can implement (have alliances, plan, evaluate, use volunteering, etc.), the CD indicators constitute a broad menu of intervention forms, and it is expected that companies tend to use only a part of them. Here the dispersion of results is greater. At one extreme is the support for education (91\%) and the other is the realization of tutorials (28\%), support for fundraising (26\%), and the integration of managers in directories of social organizations (26\%). The transfer of technical knowledge (71\%), support for labor insertion (72\%), the carrying out of training activities by the company's personnel (70\%), and the use of technical knowledge are also practiced by a significant percentage of companies(64\%). It should also be noted that $23 \%$ of companies apply nine or more of these practices, $47 \%$ use between six and eight of them, and 30\% apply only three or four. Taken together, these data suggest that most of the companies in the sample follow the guidelines of the ISO 26000 Guidance about community development. So, as a whole, the data validate Hypothesis 1.

Table 3 presents descriptive information on the scales constructed to measure the degree to which companies apply the guidelines of the ISO Guide 26000 in the two dimensions of CSR for the community (SCAACP and SCACD). We can observe that companies are better qualified in the scale measured by the ACP and the dispersion is higher in the scale measured by the CD. Nevertheless, both scales are correlated with each other: the Pearson correlation coefficient was 0.413 , with a bilateral 
significance level of 0.004 . This result suggests that companies tend to incorporate the guidelines of the guide for both dimensions simultaneously. So, Hypothesis 2 is validated.

Table 3. Descriptive information of the scales that measure the degree of incorporation of the guidelines of the ISO 26000 Guide on ACP and CD.

\begin{tabular}{ccccccc}
\hline Indicator & $\begin{array}{c}\text { Description of the } \\
\text { Indicator }\end{array}$ & Average & Median & $\begin{array}{c}\text { Standard } \\
\text { Deviation }\end{array}$ & Minimum & Maximum \\
\hline SCAACP & $\begin{array}{c}\text { Active participation in } \\
\text { the community (0-1) }\end{array}$ & 0.71 & 0.73 & 0.1641 & 0.27 & 0.91 \\
SCACD & $\begin{array}{c}\text { Community } \\
\text { Development (0-1) }\end{array}$ & 0.52 & 0.54 & 0.1904 & 0.00 & 0.92 \\
\hline
\end{tabular}

Table 4 transcribes the Pearson correlation coefficients and the respective levels of bilateral significance resulting from the correlation analysis between the variables SCAACP and SCACD with four different ways of defining CSR. The degree of agreement with each of these definitions was measured by a Likert scale of five values, where the score five corresponds to a total agreement with the content of each sentence and the one corresponds to total disagreement. A positive correlation was only found between the SCAACP variable and the definition that interprets CSR as a way of returning to society what the company receives from it (def3). If we take into account that the ISO 26000 Guide defines CSR as responsible management of the company's impacts on its stakeholders and the environment, these results suggest that the application of the guidelines in this guide, for the specific case of the ACP and CD, is independent of the adoption of the CSR definition proposed in this document. In addition, this correlation is apparently inconsistent, due to the fact that def3 is associated with the concept of corporate citizenship, which tends to reduce CSR to philanthropic behavior. In sum, these results reject Hypothesis 3.

Table 4. Correlation between ACP and CD with the way of conceptualizing the CSR by those responsible for managing CSR activities towards the community.

\begin{tabular}{|c|c|c|c|c|}
\hline & Affirmations & & $\mathrm{ACP}$ & CD \\
\hline Def1 & $\begin{array}{l}\text { It is a way of managing the company } \\
\text { based on ethical principles }\end{array}$ & $\begin{array}{l}\text { Pearson correlation } \\
\text { signification } \\
(2 \text {-tailed })\end{array}$ & $\begin{array}{c}0.132 \\
(0.375)\end{array}$ & $\begin{array}{c}0.193 \\
(0.194)\end{array}$ \\
\hline Def2 & $\begin{array}{l}\text { It is a form of management based on } \\
\text { contemplating the needs of the } \\
\text { company's stakeholders and building } \\
\text { win-win relationships with (and } \\
\text { among) them }\end{array}$ & $\begin{array}{l}\text { Pearson correlation } \\
\text { signification } \\
\text { (2-tailed) }\end{array}$ & $\begin{array}{c}0.035 \\
(0.816)\end{array}$ & $\begin{array}{l}-0.183 \\
(0.219)\end{array}$ \\
\hline Def3 & $\begin{array}{l}\text { It is a way of giving back to society } \\
\text { what the company receives from it }\end{array}$ & $\begin{array}{l}\text { Pearson correlation } \\
\text { signification } \\
\text { (2-tailed) }\end{array}$ & $\begin{array}{c}0.263 \\
(0.074)\end{array}$ & $\begin{array}{l}-0.007 \\
(0.961)\end{array}$ \\
\hline Def4 & $\begin{array}{l}\text { It is the desire to reduce the negative } \\
\text { impacts of the operation of the } \\
\text { company on stakeholders and society }\end{array}$ & $\begin{array}{l}\text { Pearson correlation } \\
\text { signification } \\
\text { (2-tailed) }\end{array}$ & $\begin{array}{l}-0.083 \\
(0.578)\end{array}$ & $\begin{array}{l}-0.177 \\
(0.234)\end{array}$ \\
\hline
\end{tabular}

The importance the companies in the sample assign to CSR was studied through a single indicator ("What importance is assigned to CSR in your company?"), which was measured with a Likert scale of five values, where one corresponds to a high importance and five to a low importance with three is an intermediate value. Table 6 presents descriptive information on this variable (IMPCSR. Table 7 transcribes the Pearson correlation coefficient and the level of bilateral significance that resulted from the correlation analysis of this variable with SCAACP and SCACD. There it can be observed that there is a correlation between the variables with an important level of significance. Thus, the greater the 
importance assigned to CSR, the greater the degree to which companies apply the guidelines of ISO 26000 on this subject. Therefore, the data validate Hypothesis 4.

To measure the degree to which companies incorporate CSR into their management, a battery of nine indicators was used, which were evaluated with a nominal scale of two values (applied or not applied). Table 5 shows the percentage of companies that qualified affirmatively in each of them. In turn, these indicators were combined to create a global indicator on the incorporation of CSR to management (INCCSR), whose values can vary between zero and one. The average value of this indicator was 0.72 , the minimum value was 0.33 , and the maximum value was one (Table 6). As can be seen in Table 7, this indicator correlates strongly with SCAACP and with SCACD, which means that the greater the degree of incorporation of CSR management practices, the greater the degree to which companies apply the guidelines of the ISO 26000 Guide on ACP and CD. Therefore, Hypothesis 5 is validated. The demonstration of Hypotheses 4 and 5 suggests that the more important CSR is for companies and the greater the incorporation of specific practices related to CSR management, the greater the degree in which the companies align their social actions with the orientations of the ISO Guide 26000 for this type of action.

Table 5. Percentage of companies that apply practices related to the incorporation of CSR to management. CSR: corporate social responsibility.

\begin{tabular}{lcc}
\hline Indicator & Indicator Description & Applicable \\
\hline INCCSR1 & Includes references to CSR in its identity statements (vision, mission, & $92 \%$ \\
INCCSR2 & and values). & $89 \%$ \\
INCCSR3 & Includes CSR in its strategic planning & $79 \%$ \\
INCCSR4 & Has a code of ethics or conduct & $62 \%$ \\
INCCSR5 & Prepares a social report or social memory (annual or bi-annual) & $75 \%$ \\
INCCSR6 & Has a CSR area or team & $49 \%$ \\
INCCSR7 & Has a person dedicated exclusively to the management of CSR & $98 \%$ \\
INCCSR8 & Involves the management team on CSR issues & $87 \%$ \\
& Global Compact Network, network of public companies that & \\
INCCSR9 & promote CSR, etc.). & $21 \%$ \\
& Has its own foundation or integrates a foundation with other & companies \\
\hline
\end{tabular}

Table 6. Descriptive information of independent variables.

\begin{tabular}{ccccccc}
\hline Indicator & Indicator Description & Average & Median & $\begin{array}{c}\text { Standard } \\
\text { Deviation }\end{array}$ & Minimum & Maximum \\
\hline IMPCSR & Importance assigned to CSR (1-5) & 1.79 & 2.00 & 0.8059 & 1.00 & 4.00 \\
\hline INCCSR & $\begin{array}{c}\text { Incorporation of CSR practices into } \\
\text { management (0-1) }\end{array}$ & 0.72 & 0.78 & 0.1778 & 0.33 & 1.00 \\
\hline CONISO & $\begin{array}{c}\text { Degree of knowledge of the guidelines } \\
\text { of the ISO Guide 26000 on CSR towards } \\
\text { the community (1-5) }\end{array}$ & 3.38 & 3.00 & 1.3761 & 1.00 & 5.00 \\
\hline APLISO & $\begin{array}{c}\text { Degree of application of the guidelines } \\
\text { of the ISO 26000 Guide on CSR towards } \\
\text { the community (1-5) }\end{array}$ & 2.77 & 3.00 & 0.8172 & 1.00 & 4.00 \\
\hline PROFAL & $\begin{array}{c}\text { How profound and bonded the alliances } \\
\text { are (1-5) }\end{array}$ & 3.78 & 3.88 & 0.7035 & 2.0 & 4.88 \\
\hline
\end{tabular}


Table 7. Correlations with independent variables between SCAACP and SCACD.

\begin{tabular}{|c|c|c|c|c|c|c|c|c|}
\hline & & SCAACP & SCACD & IMPRSE & INCRSE & CONISO & APLISO & PROFAL \\
\hline \multirow{2}{*}{ SCAACP } & Pearson correlation & 1 & $0.413^{* *}$ & $-0.351 *$ & $0.448^{* *}$ & -0.117 & -0.355 & $0.481^{* *}$ \\
\hline & following (bilateral) & & 0.004 & 0.016 & 0.002 & 0.435 & 0.054 & 0.001 \\
\hline \multirow{2}{*}{ SCACD } & Pearson correlation & 0.413 ** & 1 & $-0.305^{*}$ & 0.275 & -0.017 & -0.350 & $0.434^{* *}$ \\
\hline & following (bilateral) & 0.004 & & 0.037 & 0.061 & 0.911 & 0.058 & 0.005 \\
\hline \multirow{2}{*}{ IMPRSE } & Pearson correlation & $-0.351 *$ & $-0.305 *$ & 1 & -0.201 & 0.016 & $0.592 * *$ & -0.076 \\
\hline & following (bilateral) & 0.016 & 0.037 & & 0.176 & 0.914 & 0.001 & 0.638 \\
\hline \multirow{2}{*}{ INCRSE } & Pearson correlation & 0.448 ** & 0.275 & -0.201 & 1 & -0.268 & -0.198 & $0.365 *$ \\
\hline & following (bilateral) & 0.002 & 0.061 & 0.176 & & 0.068 & 0.294 & 0.019 \\
\hline \multirow{2}{*}{ CONISO } & Pearson correlation & -0.117 & -0.017 & 0.016 & -0.268 & 1 & $0.618^{* *}$ & -0.122 \\
\hline & following (bilateral) & 0.435 & 0.911 & 0.914 & 0.068 & & 0.000 & 0.446 \\
\hline \multirow{2}{*}{ APLISO } & Pearson correlation & -0.355 & -0.350 & $0.592 * *$ & -0.198 & $0.618^{* *}$ & 1 & 0.047 \\
\hline & following (bilateral) & 0.054 & 0.058 & 0.001 & 0.294 & 0.000 & & 0.808 \\
\hline \multirow{2}{*}{ PROFAL } & Pearson correlation & $0.481 * *$ & $0.434^{* *}$ & -0.076 & $0.365 *$ & -0.122 & 0.047 & 1 \\
\hline & following (bilateral) & 0.001 & 0.005 & 0.638 & 0.019 & 0.446 & 0.808 & \\
\hline
\end{tabular}

** The correlation is significant at the 0.01 level (2-tailed). * The correlation is significant at the 0.05 level (2-tailed).

The knowledge of the guidelines of the ISO 26000 Guide on this subject (CONISO) was studied by means of a single indicator ("How do you rate your knowledge on the CSR guidelines for the community established in the ISO Guide 26000?"). For its part, the application of these guidelines (APLISO) was also studied through a single indicator ("How do you rate the degree of application in your company of those guidelines of the ISO 26000 Guide?"). Both indicators were measured with a Likert scale of five values, where the value one corresponds to a high level (of knowledge or application), five corresponds to a zero level, and three is an intermediate value. In Table 6 it can be seen that the mean of the distribution of the first variable is 3.4 and the median is 3.0, while the values of the mean and the median of the second variable are, respectively, 2.8 and 3.0. Both groups of figures indicate that the knowledge and the application of the orientations of the ISO 26000 Guide on ACP and $C D$ are low. It should be noted that the second question was only applied to those who said they had some knowledge of the subject.

The analysis of the correlation between these variables with SCAACP and SCACD showed that the application of the guidelines of the ISO 26000 guides on ACP and CD is independent of the knowledge of these guidelines (CONISO), but it correlates with the perception that respondents have of that application (APLISO). It should be noted that if the cases in which there is no knowledge of the subject are excluded from the analysis (that is, the cases in which five were answered in CONISO), among the remaining cases the degree of knowledge correlates with SCAACP (Pearson coefficient $=-0.372$ with a significance level of 0.036 ) and with SCACD (Pearson coefficient $=-0.366$ with a significance level of 0.039). This suggests that the application of the orientations of the ISO 26000 Guide correlates with the knowledge about these orientations when those responsible for managing CSR towards the community have some knowledge of the subject. In summary, the results validate Hypotheses 7 and 6, but the latter only in the case where those responsible for managing CSR towards the community possess some minimum degree of knowledge of the guidelines of the ISO 26000 Guide on the practices of CSR addressed to the community.

To measure the depth of the alliances, a battery of nine indicators was used, each of which represents one of the dimensions of the model proposed by Austin et al. (2004), measured with a Likert scale of five values. These indicators were applied to the relationship of each company with the institution that considers its main strategic ally for its CSR actions towards the community. Table 8 includes descriptive information on each of them. There it can be observed that in some of the indicators quite high values are registered (level of commitment of the company, importance of the relationship for the mission of the company and strategic value of the relationship). The lowest values are recorded in the management complexity of the relationship and in the spectrum of joint activities that are carried 
out. By combining these nine indicators, a scale measuring the depth of these alliances (PROFAL) was built. The reliability of this scale was validated by the Cronbach's alpha test, for which the value was 0.992 . Table 6 presents descriptive information on this variable and in Table 7 it can be observed that it correlates with SCAACP (Pearson coefficient equal to 0.481 with a significance level of 0.001 ) and with SCACD (Pearson correlation coefficient equal to 0.434, with a significance level of 0.005). Therefore, data validate Hypothesis 9.

Table 8. Descriptive information of the indicators implemented to measure the depth of the alliances.

\begin{tabular}{ccccc}
\hline Indicator & Indicator Description & Average & Median & $\begin{array}{c}\text { Standard } \\
\text { Deviation }\end{array}$ \\
\hline Al1 & Level of commitment of the company & 4.6 & 5.0 & 0.983 \\
Al2 & The importance this relationship has for the MISSION of the & 4.3 & 4.0 & 1.106 \\
Al3 & company & 3.7 & 3.5 & 1.440 \\
Al4 & The magnitude of the resources provided by the company & 3.7 & 4.0 & 1.459 \\
Al5 & Diversity of resources provided by the company & 3.4 & 3.0 & 1.451 \\
Al7 & Spectrum of activities & 4.0 & 4.0 & 1.268 \\
Al8 & Level of interaction & 3.2 & 3.0 & 1.595 \\
Al9 & Complexity management has within the relationship & 4.3 & 5.0 & 1.217 \\
\hline
\end{tabular}

\section{Conclusions}

Despite the conceptual and practical importance of ISO Guide 26000, the academic world seems to pay little attention to it. In this sense, this document contributes to the development of research on the application of the guidelines in one of the dimensions of CSR: the relationship of the company with the community in which it operates. In this order of ideas, the first conclusion of this research is that the vast majority of companies that claim to have adopted CSR in their management are applying these guidelines to a large extent, as can be seen from the fact that a large part of the 24 practices evaluated have been adopted at least by half of the companies studied, and that many apply a large number of these practices simultaneously. The second conclusion goes into further detail. The results suggest that within this setting, the most advanced companies in terms of incorporating CSR practices in management (including strategic planning, codes of ethics, personnel dedicated exclusively to CSR, public accountability for social and environmental impacts through social or sustainability reports, etc.) tend to apply these orientations more intensely. This suggests that the more companies move forward in introducing CSR as a management philosophy transversal to their operation, the greater the likelihood that they will design and implement social actions with the potential to generate positive impacts in terms of community development. They may be directly involved in different ways. In other words, the incorporation of CSR to management moves companies away from welfare and, probably, from the reduction of CSR to philanthropic practices or social marketing.

The third conclusion that should be highlighted is the correlation found between the level of active participation of companies in the implementation of social actions (ranging from zero involvement, as in the case of donations, to strong commitments such as volunteering and labor inclusion of vulnerable groups) and the type of results that those actions generate in the target population (welfare or empowerment and sustainability). This suggests that companies align their way of working in the communities with the objectives sought; that is, the companies seem to be clear that the actions that produce sustainable impacts in the target institutions and individuals require a greater degree of involvement based on collaborative work, planning, evaluation of results, and the participation of their human resources. This conclusion is of practical importance for companies and for the organizations that receive their social actions; for the former because it contributes to the alignment of objectives and actions, and for the latter because it helps them to choose the business partners best suited to their needs.

The fourth interesting conclusion, at least from the theoretical point of view, is that the application of these orientations turns out to be independent of the knowledge that the people in charge of managing 
CSR have towards the community. This situation could likely be explained by the fact that the ISO 26000 guide gathers the accumulated practical experience of the business sector and that, therefore, many companies had already incorporated them before this guide was prepared. Perhaps there are other explanations, which could be sought through specific investigations. Finally, it is important to highlight the fifth conclusion, which refers to the relationship between the application of the ISO Guide 26000 guidelines considered in this research and the construction of social alliances between the companies studied and the social organizations with which they are linked. The research allows us to conclude that the application of ISO guidelines on CSR to the community is more likely in contexts where companies and social organizations build strong alliances.

This research has some methodological limitations. Firstly, there are the limitations derived from the lack of statistical representation of the sample studied, because the setting was not delimited in a strict manner and because we worked with a non-probabilistic sample of companies. Secondly, the small size of the sample made it difficult to perform segmentation analyses and extract solid conclusions in the correlation studies. In the particular case of the latter, size implies working with large margins of error and, therefore, greater demands to establish statistically significant relationships. The third limitation refers to several of the scales used, in particular the nominal variables of two values. The option for this type of variable, derived from the nature of the measured objects (for example, it does not make sense to use a Likert scale to measure the performance of internships and tutorials or the publication of a social report), limited the possibility of using sophisticated statistical analysis techniques. A fourth limitation is given by the fact that the research was conducted in only one country, which may introduce biases associated with factors such as culture, the specific way of working of third sector organizations, the role played by the state in the solution of social problems, and the degree of development of CSR.

Being pioneering research in relation to the subject studied, the document is limited in terms of the analysis of previous publications on which to base the formulation of hypotheses, guide the methodological approach, and perform comparative analyses. Although the scarce academic literature on the ISO 26000 Guide and particularly on its application is not an intrinsic weakness of the research, this requires caution in relation to the indicators used and the results obtained.

Despite all these limitations, this research constitutes a contribution to scientific production on the problem studied. This is firstly because it provides empirical evidence in a context where there is little research on the subject. Secondly, it proposes an instrument with which to measure the orientations of the ISO 26000 Guide on Active Participation and Community Development. Although this instrument has methodological limitations, it can serve as a basis for the construction of more powerful instruments. Thirdly, this work provides a set of indicators designed to measure the depth of social alliances, based on the theoretical development of the team led by James Austin, the main academic reference in this area. Although this battery uses a single indicator for each of the dimensions proposed by these authors, the statistical reliability of the scale built on them suggests that the process of building a tool to study the depth of alliances from a quantitative perspective is well underway. In addition, the research addresses the study of social alliances in the general framework of CSR practices towards the community, contributing knowledge in a little-explored field since the most research on social alliances is found in the specific field of the markets at the base of the pyramid and in inclusive businesses. Finally, this work leaves open several questions, which become new research problems that need to be addressed in the future. Perhaps the most interesting of these is the apparent paradox in that the application of ISO 26000 guidance on ACP and CD is independent of knowledge of its recommendations.

Author Contributions: Conceptualization, O.D.L., L.J.A.P. and P.C.; methodology, O.D.L., L.J.A.P. and P.C.; software, O.D.L. and P.C.; validation, O.D.L., A.D.R.G., L.J.A.P., L.A.V.O. and P.C.; formal analysis, O.D.L., A.D.R.G., L.J.A.P., L.A.V.O. and P.C.; investigation, O.D.L., A.D.R.G., L.J.A.P., L.A.V.O. and P.C.; resources, O.D.L. and P.C.; data curation, O.D.L., A.D.R.G., L.J.A.P., L.A.V.O. and P.C.; writing-original draft preparation, O.D.L. and L.J.A.P.; writing-review and editing, O.D.L., A.D.R.G., L.J.A.P., L.A.V.O. and P.C.; visualization, O.D.L., A.D.R.G., L.J.A.P., L.A.V.O. and P.C.; supervision O.D.L., L.J.A.P.; project administration, O.D.L., L.J.A.P.

Funding: This research received no external funding. 
Conflicts of Interest: The authors declare no conflict of interest.

\section{References}

Abad, Francisco. 2002. Ocho claves de la acción social empresarial en España. Marketing y Ventas 5: 40-45.

Alonso Ubieta, Suyen, Mauricio Dierckxsens Uitdewilligen, María del Pilar Gonzalo Garrido, Karina López Fernández, Laura Sariego Kluge, Jorge Sariego Mac-Ginty, Jorge Valenciano Salazar, and Marije Van Lidth de Jeude. 2009. Alianzas para el desarrollo: Motor para la Responsabilidad Social. Casos de organizaciones públicas y privadas en Costa Rica. Costa Rica: Fundación para la Sostenibilidad y la Equidad.

Austin, James. 2003. El desafío de la colaboración: Cómo las organizaciones sin fines de lucro y las empresas comerciales alcanzan el éxito mediante alianzas estratégicas. Buenos Aires: Granica.

Austin, James, and Michael Chu. 2006. La empresa privada y los sectores de bajos ingresos. Revista Harvard Review of Latin América 6: 3-5.

Austin, James, Gustavo Herrero, and Ezequiel Reficco. 2004. La nueva ruta: Alianzas sociales estratégicas. Harvard Business Review Edición Latinoamérica 82: 31-40.

Austin, James, Ezequiel Reficco, Gabriel Berger, Rosa Fischer, Roberto Gutiérrez, Mnladen Koljatic, and Enrique Ogliastri. 2005. Alianzas sociales en América Latina. Enseñanzas extraídas de colaboraciones entre el sector privado y organizaciones de la sociedad civil. Bogotá: Banco Interamericano de Desarrollo.

Austin, James, Roberto Gutiérrez, Enrique Ogliastri, and Ezequiel Reficco. 2009. Aprovechar la convergencia. Academia Revista Latinoamericana de Administración 43: 93-106.

Barnett, Michael. 2007. Stakeholder Influence Capacity and the Variability of Financial Returns to Corporate Social Responsibility. Academy of Management Review 32: 794-816. [CrossRef]

Carroll, Arnold. 1999. Corporate Social Responsibility: Evolution of Definitional Construct. Business and Society 38: 268-95. [CrossRef]

Carroll, Arnold. 2015. Corporate social responsibility: The centerpiece of competing and complementary frameworks. Organizational Dynamics 44: 87-96. [CrossRef]

Dahan, Nicolas, Jonatahn Doh, Jennifer Oetzel, and Michael Yaziji. 2010. Corporate-NGO Collaboration: Co-creating New Business Models for Developing Markets. Long Range Planning 43: 326-42. [CrossRef]

Dahlsrud, Alexander. 2008. How Corporate Social Responsibility is defined: An Analysis of 37 Definitions. Corporate Social Responsibility and Environmental Management 15: 1-13. [CrossRef]

Davis, Keith, and Robert Blomstrom. 1966. Business and Its Environment. New York: McGraw-Hill.

DERES. 2015. Las mejores prácticas. 2014. Reconocimiento al impacto positivo de las mejores prácticas de RSE. Montevideo: DERES, Available online: http://deres.org.uy/wp-content/uploads/Reconocimientos-2014-Final. pdf (accessed on 5 October 2018).

DERES. 2016. Las mejores prácticas. 2015. Reconocimiento al impacto positivo de las mejores prácticas de RSE. Montevideo: DERES, Available online: http://deres.org.uy/wp-content/uploads/Publicaci\%C3\%B3n-Rec-2015-final-1.pdf (accessed on 5 October 2018).

DERES. 2017. Las mejores prácticas. 2016. Reconocimiento al impacto positivo de las mejores prácticas de RSE. Montevideo: DERES, Available online: http://deres.org.uy/wp-content/uploads/RECONOCIMIENTO-DERES-Public-12. 2016-Com-CVL-MA-ET-CV-3.pdf (accessed on 5 October 2018).

Eilbert, Henry, and Robert Parket. 1973. The current status of corporate social responsibility. Business Horizons 16: 5-14.

Epstein, Edwin. 1987. The corporate social policy process: Beyond business ethics, corporate social responsibility, and corporate social responsiveness. California Management Review 29: 99-114. [CrossRef]

Fisher, Rosa María, Mónica Bose, Paulo da Rocha Ferreira, and Graziella Comini. 2010. Gestión de residuos sólidos: Inserción de la población de bajos ingresos en la cadena de valor. In Negocios Inclusivos. Iniciativas de mercado con los pobres de Iberoamérica. Edited by Patricia Márquez, Ezequiel Reficco and Gabriel Berger. Colombia: BID, pp. 205-39.

Frederick, William, Post James, and Keith Davis. 1992. Business and Society. Corporate Strategy, Public Policy, Ethics. London: McGraw-Hill.

Freeman, Edward. 1983. Stockholders and Stakeholders: A New Perspective on Corporate Governance. California Management Review 25: 88-106. [CrossRef] 
Garriga, Elizabeth, and Domenec Melé. 2004. Corporate social responsibility theories: Mapping the territory. Journal of Business Ethics 53: 51-71. [CrossRef]

Glasbergen, Pieter, Frank Biermann, and Arthur Mol. 2007. Partnerships, Governance, and Sustainable Development. Reflections on Theory and Practice. Reino Unido: Edward Elgar Publishing.

Hammond, Allen, William Kramer, Rober Kats, Julia Tran, and Courtland Walker. 2007. Los siguientes cuatro mil millones: Tamaño del mercado y estrategia de Negocios en la base de la pirámide. Washington, DC: World Resources Institute International Finance Corporation.

Hart, Stuart, and Clainton Christensen. 2002. The great leap: Driving innovation from the base of the pyramid. MIT Sloan Management Review 44: 51-56.

Hopkins, Michael. 1998. The Planetary Bargain: Corporate Social Responsibility Comes of Age. London: Macmillan. ISO. 2011. Guía de Responsabilidad Social. Montevideo: UNIT.

James, Leena. 2012. Sustainable Corporate Social Responsibility-An analysis of 50 definitions for a period of 2000-2011. International Journal of Multidisciplinary Research 2: 169-93.

Johnson, Harold. 1971. Business in Contemporary Society: Framework and Issues. Belmont: Wadsworth.

Jones, Tomas. 1980. Corporate social responsibility revisited, redefined. California Management Review 2: 59-67. [CrossRef]

Khoury, George, Janet Rostami, and Lynn Peri Turnbull. 1999. Corporate Social Responsibility: Turning Words into Action. Ottawa: Conference Board of Canada.

Kok, Peter, Ton Van der Wiele, Richard McKenna, and Alan Brown. 2001. Corporate Social Responsibility Audit within a Quality Management Framework. Journal of Business Ethics 31: 285-97. [CrossRef]

Kotler, Philp, and Nancy Lee. 2005. Corporate Social Responsibility: Doing the Most Good for Your Company and Your Cause. Hoboken: John Wiley \& Sons.

Licandro, Oscar. 2013. Modelos para el análisis de los negocios inclusivos: Construcción mediante el estudio de casos. Telos 15: 32-48.

Licandro, Oscar, Lisandro Alvarado-Peña, Edgard Sansore, and Juana Navarrette. 2019. Responsabilidad Social Empresaria: Hacia la conformación de una tipología de definiciones. Revista Venezolana de Gerencia 24: 281-99.

Lichtenstein, Donald, Minette Drumwright, and Bridgette Braig. 2004. The Effect of Corporate Social Responsibility on Customer Donations to Corporate-Supported Nonprofits. Journal of Marketing 68: 16-32. [CrossRef]

London, Ted, and Ravi Anupindi. 2012. Using the base-of-the-pyramid perspective to catalyze interdependence-based collaborations. Proceedings of the National Academy of Sciences of the United States of America 31: 12338-43. [CrossRef] [PubMed]

London, Ted, and Stuart Hart. 2004. Reinventing strategies for emerging markets: Beyond the transnational model. Journal of International Business Studies 35: 350-70. [CrossRef]

Márquez, Patricia, Ezequiel Reficco, and Gabriel Berger. 2010. Negocios Inclusivos. Iniciativas de mercado con los pobres de Iberoamérica. Colombia: BID.

Peloza, John, and Loren Falkenberg. 2009. The role of collaboration in Achieving Corporate Social Responsibility Objectives. California Management Review 51: 95-113. [CrossRef]

Pfitzer, Mark, Vavlerie Bockstette, and Mike Stamp. 2013. Innovating for Shared Value: Companies that deliver both social benefit and business value rely on five mutually reinforcing elements. Harvard Business Review 91: 100-9.

PNUD. 2008. Las Empresas Frente al desafío de la Pobreza: Estrategias Exitosas. New York: PNUD.

Porter, Michael, and Michael Kramer. 2011. Valor Compartido. Cómo reinventar el capitalismo y crear una oleada de innovación y crecimiento. Harvard Business Review -Edición América Latina 89: 33-49.

Prahalad, Coimbatore, and Stuart Hart. 2002. The Fortune at the bottom of the pyramid. Strategy Business 26: 2-14. [CrossRef]

Prats, Joan. 2001. Gobernabilidad democrática para el desarrollo humano: Marco conceptual y analítico. Revista Instituciones y Desarrollo 10: 103-48.

Preston, Lee, and James Post. 1975. Private Management and Public Policy: The Principle of Public Responsibility. Englewood Cliffs: Prentice Hall.

Ramos, Joao, and Iñaki Periáñez. 2003. Delimitación del Marketing con Causa o Marketing Social Corporativo mediante el análisis de empresas que realizan acciones de responsabilidad social. Cuadernos de Gestión 3: 65-82. 
Ramos, Eva, Ramón Pueyo, and Jesús Llaría. 2004. Las organizaciones de la Sociedad Civil y la Responsabilidad Social Corporativa. Algunos casos destacables. Zaragoza: Fundación Ecología y Desarrollo.

Recio, Manuel, and María Teresa Martín. 2002. Marketing con causa: Entre la filantropía y el beneficio empresarial. Marketing y Ventas 51: 60-63.

Reficco, Ezequiel, and Alfred Vernis. 2010. Ecosistemas organizacionales para fortalecer negocios inclusivos. In Negocios Inclusivos. Iniciativas de mercado con los pobres de Iberoaméria. Edited by En Márquez Patricia, Reficco Ezequiel and Berger Gabriel. Colombia: BID, pp. 127-72.

Social Enterprise Knowledge Network. 2006. Gestión efectiva de emprendimientos sociales: Lecciones extraídas de empresas y organizaciones de la sociedad civil en Iberoamérica. Washington, DC: Banco Interamericano de Desarrollo.

Steiner, George. 1971. Business and Society. New York: Random House.

Varadarajan, Rajan, and Anil Menon. 1988. Cause-Related Marketing: A Coalignment of Marketing Strategy and Corporate Philanthropy. Journal of Marketing 52: 58-74. [CrossRef]

WBCSD. 2000. Corporate Social Responsibility: Making Good Business Sense. Geneva: World Business Council for Sustainable Development.

WBCSD. 2006. Oportunidades para reducer la pobreza. Una guía de campo. Geneva: World Business Council for Sustainable Development.

Zenisek, Thomas. 1979. Corporate social responsibility: A conceptualization based on organizational literature. Academy of Management Review 4: 359-68. [CrossRef]

(C) 2019 by the authors. Licensee MDPI, Basel, Switzerland. This article is an open access article distributed under the terms and conditions of the Creative Commons Attribution (CC BY) license (http://creativecommons.org/licenses/by/4.0/). 